\title{
Effects of gene polymorphisms of metabolic enzymes on the association between red and processed meat consumption and the development of colon cancer; a literature review
}

\author{
S. Doaei ${ }^{1,2}$, M. Hajiesmaeil ${ }^{3}$, A. Aminifard ${ }^{4}$, S. A. Mosavi-Jarrahi ${ }^{5}$, M. E. Akbari ${ }^{2}$ and M. Gholamalizadeh ${ }^{6}$ \\ ${ }^{1}$ Natural Products and Medicinal Plants Research Center, North Khorasan University of Medical Sciences, Bojnurd, Iran \\ ${ }^{2}$ Cancer Research Center (CRC), Shabid Beheshti University of Medical Sciences, Tehran, Iran \\ ${ }^{3}$ Department of Biology, Parand Branch, Islamic Azad University, Parand, Iran \\ ${ }^{4}$ Food Sciences and Industry, Khouzestan Sciences and Research Branch, Islamic Azad University, Khouzestan, Iran \\ ${ }^{5}$ Faculty of Medical School, Shabid Beheshti University of Medical Sciences, Tebran, Iran \\ ${ }^{6}$ Student Research Committee, Cancer Research Center, Shahid Beheshti University of Medical Sciences, Tehran, Iran
}

(Received 5 March 2018 - Final revision received 8 June 2018 - Accepted 17 August 2018)

Journal of Nutritional Science (2018), vol. 7, e26, page 1 of 7

doi:10.1017/jns.2018.17

\section{Abstract}

The role of environmental factors and genetic susceptibility in the development of colon cancer (CC) has been already proven, but the role of gene polymorphisms in modifying the risk of environmental factors such as nutritional factors is still unknown. This study aimed to investigate the effect of polymorphisms of involved genes in the association between red meat consumption and the development of CC. The present review was carried out using keywords such as polymorphism and/or protein and/or red meat and/or processed meat and/or colon cancer. PubMed and Science Direct databases were used to collect all related articles published from 2001 to 2017. The presence of SNP in the coding genes of proteins involved in metabolism of nutrients could play significant roles in the extent of the effects of nutrition in the development of CC. The effect of dietary proteins greatly depends on the polymorphisms in the metabolising genes of these substances. Gene polymorphisms may have a role in colorectal cancer risk, especially in people with high meat intake, and this leads to a difference in the effects of meat consumption in different individuals. To conclude, dietary recommendations for the prevention and control of CC should be modified based on the genotype of different individuals. Increasing our knowledge on this field of nutritional genomics can lead to personalised preventive and therapeutic recommendations for CC patients.

Key words: Colon cancer: Polymorphisms: Protein: Colorectal cancer

Colon cancer (CC), also known as colorectal cancer (CRC), is the third most commonly diagnosed malignancy and the fourth leading cause of cancer-related deaths worldwide ${ }^{(1)}$. The prevalence of CC among Iranian people was between 7 and 8 per 100000 people, with a significant increase over the last several years ${ }^{(2)}$.

In most cases, $\mathrm{CC}$ occurs in people aged 50 years or older and the risk of $\mathrm{CC}$ recurrence is increased with age $\mathrm{e}^{(3)}$. It has been reported that about 6 to $7 \%$ of CC cases have a genetic origin. Approximately 10 to $15 \%$ of CRC occur in patients where at least one of his/her relatives also had $\mathrm{CC}^{(4)}$. Also, some hereditary syndromes are also effective on the risk of CC including Lynch syndrome and familial adenomatous polyposis syndrome ${ }^{(5)}$. In addition, some environmental factors such as alcohol consumption, smoking, physical inactivity, high-fat diet and consumption of red and processed meat are

Abbreviations: CC, colon cancer; COX, cyclo-oxygenase; CRC, colorectal cancer; CYP, cytochrome P450; MutS, mutator S; NAT, N-acetyltransferase; NER, nucleotide excision repair; XP, xeroderma pigmentosum.

* Corresponding author: M. Gholamalizadeh, email Gholamalizadeh@sbmu.ac.ir 
also considered as risk factors for $\mathrm{CRC}^{(3)}$. Recent studies reported that change in the expression level of some genes is also a mechanism involved in the effects of these environmental factors ${ }^{(6-8)}$. Moreover, some people are at higher risk for CC because of their genotype ${ }^{(9)}$. In other words, the development of CRC is a complex process that involves positive and negative interactions between genes and environmental factors. In the present study, the effects of the interactions between gene polymorphisms and red and processed meat consumption on the risk of CC have been reviewed.

\section{Red and processed meat and colon cancer}

Many studies have shown that there is a significant association between a red and processed meat-rich diet and $\mathrm{CRC}^{(10,11)}$. This association has been attributed to several dietary factors, including heterocyclic amines, aromatic hydrocarbons produced during high temperature heating processes, $N$-nitrosamines that are found in many food products after nitrite addition and processed meat that contains high levels of preservatives. The polymorphisms in some genes involved in the metabolism of these components and risk of CC are discussed below.

\section{$\mathrm{N}$-acetyltransferases}

Many studies have examined the enzymes involved in the metabolism of amines and heterocyclic amines and suggested a significant relationship between polymorphisms of these enzymes and risk of $\mathrm{CC}^{(12,13)}$. Heterocyclic amines are produced during cooking meat at high temperatures. $\mathrm{N}$-acetyltransferases (NAT) are important enzymes in the metabolic activation of heterocyclic amines, which are found in two forms of NAT1 and NAT2. The rs1495741 polymorphism of NAT2 was strongly related to its activity and the GG, AG and AA genotypes are classified as enzymes with rapid, intermediate and slow activity, respectively. In people with the GG genotype of this polymorphism, there is a strong association between the consumption of red meat and the risk of $\mathrm{CRC}^{(12-14)}$. Another study reported that cooking meat at a high temperature increased the risk of CC in people with NAT2 gene polymorphisms ${ }^{(15)}$. However, Barrett et al. ${ }^{(16)}$ provide no support for the hypothesis that those with the fast phenotype of NAT2 are at increased risk of CRC.

A study was conducted on 147 CRC patients (seventy-six women and ninety men); the cancer risk in women was found to be lower in the NAT intermediate activity phenotype, but this difference was not found in men. It has also been reported that in people with the GG genotype of NAT2 G857A, meat intake more than three times per week increased CRC risk ${ }^{(17)}$. However, some other studies failed to find any interaction between GG genotype, meat intake and CRC $^{(18-20)}$. For example, Chan et al. ${ }^{(20)}$ reported that there was no interaction between the amount of meat consumed with NAT1 and NAT2 and the risk of developing CRC. Overall, it can be concluded that NAT2 gene polymorphisms may have a role in CRC risk, especially in people with high meat intake.

\section{Cyclo-oxygenases}

Cyclo-oxygenases (COX) play a key role in converting arachidonic acid into prostaglandins. Red meat contains a substantial amount of arachidonic acid and most probably is involved in the inflammatory response and initiation of CC especially in people with a polymorphism in the COX-1 and COX-2 genes. This polymorphism occurs in the promoter region of the gene, resulting in a possible increase in gene expression with consequent elevation of levels of the COX-2 protein. Individuals who carry the polymorphisms that could affect the expressions of $\mathrm{COX}-2$ are more susceptible to $\mathrm{CC}^{(21)}$. There are two isoforms of the COX enzyme, COX-1 (or prostaglandin-endoperoxide synthase 1; PTGS1), that produces PG1, and COX-2 (or PTGS2), which produces PG2. The rs20417 $(-765 \mathrm{G}>\mathrm{C})$ and rs5275 $(8473 \mathrm{~T}>\mathrm{C})$ polymorphisms of COX-2 play an important role in many cancers such as gastric cancer, prostate cancer and CRC. Some studies have also shown that the COX-2 rs1195AA genotype can also play a supportive role in the development of CRC. Makar et al. ${ }^{(22)}$ showed that polymorphism rs20417 $(-765 \mathrm{G}>\mathrm{C})$ in the $C O X-2$ gene increases the risk of rectal cancer by up to two times higher than others. No significant relationship was reported between COX-1 gene polymorphisms and CRC in this study. In one meta-analysis study, there was a significant relationship between the COX-2 rs20417 polymorphism and the risk of CRC in an Asian population ${ }^{(23)}$. Andersen et al. ${ }^{(24)}$ suggested that the relationship between the COX-2 rs20417 polymorphism and the risk of CRC is influenced by dietary meat intake and $C O X-2$ rs20417 risk allele carriers were at $8 \%$ increased risk of CRC per $25 \mathrm{~g} / \mathrm{d}$ higher red meat or processed meat intake. Generally, it can be concluded that COX-2 gene polymorphisms may have a role in CRC risk, especially in people with higher meat intake.

\section{Cytochrome P450 2E1 and cytochrome P450 1A2}

$\mathrm{CRC}$ is associated with environmental factors such as cigarette smoking, and consuming cooked meats and fish at high temperature. These factors result in the formation of carcinogenic compounds including polycyclic aromatic hydrocarbons, arylamines and heterocyclic amines. The cytochrome P450 (CYP) enzymes are critically important for the metabolism of these carcinogens by $\mathrm{N}$ oxidation ${ }^{(25)}$. CYP2E1 is an enzyme that plays a key role in the metabolism of nitrosamines and other carcinogens ${ }^{(26)}$. The RsaI polymorphism of CYP2E1 (C2 allele) is associated with an increased risk of $\mathrm{CRC}^{(26,27)}$. The RsaI polymorphism has been shown to affect its transcription level. The variant type of this polymorphic site can enhance transcription and increase the level of CYP2E1 enzymic activity in vitro ${ }^{(10)}$.

Some studies have also shown that individuals carrying a variant of the $\mathrm{C} 2$ allele have lower enzyme activity. In the Hawaiian population, it has been shown that the risk of CC has decreased in subjects carrying the RsaI C2 allele ${ }^{(27)}$. On the other hand, a study in China showed that homozygous individuals for the $\mathrm{C} 2$ allele were also more likely to develop CRC $^{(28)}$. Moreover, in some other studies, no relationship was observed between RsaI polymorphisms and the risk of 
Table 1. Summary of study descriptions and outcomes

\begin{tabular}{|c|c|c|c|c|c|}
\hline Reference & Title & Study design & Sample characteristic & Examined components & Main findings \\
\hline \multicolumn{6}{|l|}{ NAT } \\
\hline $\begin{array}{l}\text { Wang et al. } \\
(2015)^{(12)}\end{array}$ & $\begin{array}{l}\text { Interaction between red meat intake and } \\
\text { NAT2 genotype in increasing the risk of } \\
\text { CRC in Japanese and African Americans }\end{array}$ & Meta-analyses & $\begin{array}{l}2744 \text { cases, } 8315 \\
\text { controls }\end{array}$ & NAT genotype (SNP rs1495741) & $\begin{array}{l}\text { In people with GG genotype (rapid NAT2 phenotype) } \\
\text { of this polymorphism, there is a strong association } \\
\text { between consumption of red meat and the risk of } \\
\text { CRC }\end{array}$ \\
\hline $\begin{array}{l}\text { Ananthakrishnan } \\
\text { et al. }(2015)^{(13)}\end{array}$ & $\begin{array}{l}\text { Red meat intake, NAT2, and risk of CRC: } \\
\text { pooled analysis of } 11 \text { studies }\end{array}$ & Pooled analysis & $\begin{array}{l}8290 \text { cases, } 9115 \\
\text { controls }\end{array}$ & $\begin{array}{l}\text { NAT2 phenotype based on } \\
\text { polymorphism at rs } 1495741\end{array}$ & $\begin{array}{l}\text { High red meat consumption was similarly associated } \\
\text { with CRC in those with a rapid/intermediate NAT2 } \\
\text { genotype }\end{array}$ \\
\hline $\begin{array}{l}\text { Barrett et al. } \\
(2003)^{(16)}\end{array}$ & $\begin{array}{l}\text { Investigation of interaction between NAT2 } \\
\text { and } \mathrm{HA} \text { as potential risk factors for CRC }\end{array}$ & $\begin{array}{l}\text { Case-control } \\
\text { study }\end{array}$ & $\begin{array}{l}484 \text { cases, } 738 \\
\text { controls }\end{array}$ & NAT2 phenotype & $\begin{array}{l}\text { This study provides no support for the hypothesis that } \\
\text { fast NAT2 acetylators are at increased risk of CRC, } \\
\text { even if exposed to high levels of HA from well-cooked } \\
\text { meat or smoking }\end{array}$ \\
\hline $\begin{array}{l}\text { Sørensen et al. } \\
(2008)^{(14)}\end{array}$ & $\begin{array}{l}\text { Prospective study of } N A T 1 \text { and } N A T 2 \\
\text { polymorphisms, tobacco smoking and } \\
\text { meat consumption and risk of CRC }\end{array}$ & $\begin{array}{l}\text { Case-control } \\
\text { study }\end{array}$ & $\begin{array}{l}379 \text { cases, } 769 \\
\text { controls }\end{array}$ & $\begin{array}{l}\text { NAT } 1 \text { and NAT2 fast and slow NAT } \\
\text { acetylator phenotypes }\end{array}$ & $\begin{array}{l}\text { There were statistically significant associations } \\
\text { between consumption of brown-dark pan-fried meat } \\
\text { and increased CRC risk. NAT1 fast acetylators had a } \\
\text { significantly higher risk of CRC than NAT1 slow } \\
\text { acetylators, whereas NAT2 acetylator phenotype did } \\
\text { not affect the CRC risk }\end{array}$ \\
\hline $\begin{array}{l}\text { Lilla et al. } \\
(2006)^{(15)}\end{array}$ & $\begin{array}{l}\text { Effect of } N A T 1 \text { and } N A T 2 \text { genetic } \\
\text { polymorphisms on CRC risk associated } \\
\text { with exposure to tobacco smoke and meat } \\
\text { consumption }\end{array}$ & $\begin{array}{l}\text { Case-control } \\
\text { study }\end{array}$ & $\begin{array}{l}505 \text { patients with } \\
\text { incident CRC, } 604 \\
\text { controls }\end{array}$ & $\begin{array}{l}\text { NAT } 1 \text { and NAT2 fast and slow NAT } \\
\text { acetylator phenotypes }\end{array}$ & $\begin{array}{l}\text { Cooking meat at high temperature increased the risk } \\
\text { of CC in people with NAT2 gene polymorphisms }\end{array}$ \\
\hline $\begin{array}{l}\text { Procopciuc et al. } \\
(2017)^{(17)}\end{array}$ & $\begin{array}{l}\text { NAT2/environmental factors and their } \\
\text { association as a modulating risk factor for } \\
\text { sporadic colon and rectal cancer }\end{array}$ & $\begin{array}{l}\text { Case-control } \\
\text { study }\end{array}$ & $\begin{array}{l}150 \text { cases, } 162 \\
\text { controls }\end{array}$ & NAT2 phenotypes & $\begin{array}{l}\text { Fried red meat, alcohol and smoking increase the risk } \\
\text { of sporadic CRC, especially of colon cancer, in the } \\
\text { case of rapid acetylators for the NAT2 variants }\end{array}$ \\
\hline $\begin{array}{l}\text { Da Silva et al. } \\
(2011)^{(18)}\end{array}$ & $\begin{array}{l}\text { NAT2 genetic polymorphisms and risk of } \\
\text { CRC }\end{array}$ & $\begin{array}{l}\text { Case-control } \\
\text { study }\end{array}$ & $\begin{array}{l}147 \text { patients with } \\
\text { CRC, } 162 \text { controls }\end{array}$ & $\begin{array}{l}\text { People with GG genotype (NAT2 fast } \\
\text { acetylators) }\end{array}$ & $\begin{array}{l}\text { Among NAT2 fast acetylators, meat intake more than } \\
\text { three times per week increased the risk of CRC }\end{array}$ \\
\hline $\begin{array}{l}\text { Tiemersma et al. } \\
(2002)^{(19)}\end{array}$ & $\begin{array}{l}\text { Meat consumption, cigarette smoking and } \\
\text { genetic susceptibility in the aetiology of } \\
\text { CRC }\end{array}$ & $\begin{array}{l}\text { Case-control } \\
\text { study }\end{array}$ & $\begin{array}{l}102 \text { incident CRC } \\
\text { cases, } 537 \text { controls }\end{array}$ & $\begin{array}{l}\text { NAT2 gene polymorphisms (NAT2 } \\
\text { fast acetylators) }\end{array}$ & $\begin{array}{l}\text { This study found no association between GG } \\
\text { genotype and CRC }\end{array}$ \\
\hline $\begin{array}{l}\text { Chan et al. } \\
(2005)^{(20)}\end{array}$ & $\begin{array}{l}\text { Prospective study of NAT2 genotypes, } \\
\text { meat intake, smoking and risk of CRC }\end{array}$ & $\begin{array}{l}\text { Nested case- } \\
\text { control study }\end{array}$ & $\begin{array}{l}183 \text { women with } \\
\text { CRC, } 443 \text { controls }\end{array}$ & NAT2 gene polymorphisms & $\begin{array}{l}\text { This study found no interaction between meat } \\
\text { consumption with NAT2 and CRC }\end{array}$ \\
\hline \multicolumn{6}{|l|}{ cox } \\
\hline $\begin{array}{l}\text { Zhu et al. } \\
(2010)^{(45)}\end{array}$ & $\begin{array}{l}-2765 \mathrm{G}>\mathrm{C} \text { and } 8473 \mathrm{~T}>\mathrm{C} \text { polymorphisms } \\
\text { of } C O X-2 \text { and cancer risk: a meta-analysis } \\
\text { based on } 33 \text { case-control studies }\end{array}$ & Meta-analyses & $\begin{array}{l}19100 \text { cases, } 29777 \\
\text { controls }\end{array}$ & $\begin{array}{l}\text { COX-2 gene, }-2765 \mathrm{G}>\mathrm{C} \text { and } 8473 \mathrm{~T} \\
>\mathrm{C} \text { polymorphisms }\end{array}$ & $\begin{array}{l}\text { This study suggested that }-765 \mathrm{G}>\mathrm{C} \text { may cause an } \\
\text { increased risk of colorectal carcinoma in those of } \\
\text { Asian descent }\end{array}$ \\
\hline $\begin{array}{l}\text { Makar et al. } \\
(2013)^{(22)}\end{array}$ & $\begin{array}{l}\text { COX-1 (PTGS1) and COX-2 (PTGS2) } \\
\text { polymorphisms, NSAID interactions, and } \\
\text { risk of colon and rectal cancers in two } \\
\text { independent populations }\end{array}$ & $\begin{array}{l}\text { Case-control } \\
\text { study }\end{array}$ & $\begin{array}{l}2053 \text { colon and } \\
\text { rectal cancer } \\
\text { patients, } 2648 \\
\text { controls }\end{array}$ & $\begin{array}{l}\text { COX-2 gene, rs20417 }(-765 \mathrm{G}>\mathrm{C}) \\
\text { polymorphism }\end{array}$ & $\begin{array}{l}\text { The rs } 20417(-765 G>C) \text { polymorphism in the } \\
C O X-2 \text { gene increases the risk of rectal cancer by } \\
\text { up to two times. However, no significant } \\
\text { relationship was reported between PTGS1 and CRC } \\
\text { in this study }\end{array}$ \\
\hline
\end{tabular}


Table 1. Continued

\begin{tabular}{|c|c|c|c|c|c|}
\hline Reference & Title & Study design & Sample characteristic & Examined components & Main findings \\
\hline $\begin{array}{l}\text { Andersen et al. } \\
(2013)^{(24)}\end{array}$ & $\begin{array}{l}\text { Interactions between diet, lifestyle and } \\
I L-10, I L-1 B \text { and } P T G S 2 / C O X-2 \text { gene } \\
\text { polymorphisms in relation to risk of CRC in } \\
\text { a prospective Danish case-cohort study }\end{array}$ & $\begin{array}{l}\text { Case-control } \\
\text { study }\end{array}$ & $\begin{array}{l}9070 \text { CRC cases, } \\
1789 \text { controls }\end{array}$ & $\begin{array}{l}\text { COX-2 gene, }-765 \mathrm{G}>\mathrm{C} \\
\text { polymorphism }\end{array}$ & $\begin{array}{l}\text { Suggested that } C O X-2-765 \mathrm{G}<\mathrm{C} \text { risk allele } \\
\text { carriers were at } 8 \% \text { increased risk of } C R C \text { per } 25 \mathrm{~g} \\
\text { red meat or processed meat intake per d }\end{array}$ \\
\hline \multicolumn{6}{|l|}{ CYP2E1 } \\
\hline $\begin{array}{l}\text { Le Marchand et al. } \\
(2002)^{(10)}\end{array}$ & $\begin{array}{l}\text { Red meat intake, CYP2E1 genetic } \\
\text { polymorphisms, and CRC risk }\end{array}$ & $\begin{array}{l}\text { Case-control } \\
\text { study }\end{array}$ & $\begin{array}{l}521 \text { patients with } \\
\text { CRC, } 639 \text { controls }\end{array}$ & Polymorphisms in CYP2E1 & $\begin{array}{l}\text { This study showed that individuals carrying a } \\
\text { variant of the } \mathrm{C} 2 \text { allele have lower enzyme activity }\end{array}$ \\
\hline $\begin{array}{l}\text { van der Logt et al. } \\
(2006)^{(28)}\end{array}$ & $\begin{array}{l}\text { Role of epoxide hydrolase, } \mathrm{NAD}(\mathrm{P}) \mathrm{H} \text { : } \\
\text { quinone oxidoreductase, CYP2E1 or } \\
\text { alcohol dehydrogenase genotypes in } \\
\text { susceptibility to CRC }\end{array}$ & $\begin{array}{l}\text { Case-control } \\
\text { study }\end{array}$ & $\begin{array}{l}371 \text { patients with } \\
\text { sporadic CRC, } 415 \\
\text { healthy controls }\end{array}$ & Polymorphisms in CYP2E1 & $\begin{array}{l}\text { Homozygous individuals for the } \mathrm{C} 2 \text { allele were also } \\
\text { more likely to develop CRC }\end{array}$ \\
\hline $\begin{array}{l}\text { Morita et al. } \\
(2009)^{(30)}\end{array}$ & $\begin{array}{l}\text { Genetic polymorphisms of CYP2E1 and } \\
\text { risk of CRC: the Fukuoka Colorectal } \\
\text { Cancer Study }\end{array}$ & $\begin{array}{l}\text { Case-control } \\
\text { study }\end{array}$ & $\begin{array}{l}685 \text { incident cases } \\
\text { of CRC, } 778 \\
\text { controls }\end{array}$ & Polymorphisms in CYP2E1 & $\begin{array}{l}\text { Risk of cancer in individuals carrying CYP2E1 Rsa } \\
\text { I C2 allele decreases in comparison with patients } \\
\text { carrying CYP2E1 96-bp insertion }\end{array}$ \\
\hline $\begin{array}{l}\text { Wang et al. } \\
(2012)^{(32)}\end{array}$ & $\begin{array}{l}\text { Carcinogen metabolism genes, red meat } \\
\text { and poultry intake, and CRC risk }\end{array}$ & $\begin{array}{l}\text { Case-control } \\
\text { study }\end{array}$ & $\begin{array}{l}577 \text { cases, } 307 \\
\text { controls }\end{array}$ & $\begin{array}{l}-154 A>C \text { polymorphism of } \\
\text { CYP1A2 }\end{array}$ & $\begin{array}{l}\text { There was a significant relationship between the } \\
-154 A>C \text { polymorphism of } C Y P 1 A 2 \text { and } \\
\text { consumption of cooked meat at high temperature } \\
\text { with the risk of CRC }\end{array}$ \\
\hline \multicolumn{6}{|c|}{ Nucleotide excision repair pathway } \\
\hline $\begin{array}{l}\text { Khan et al. } \\
(2000)^{(37)}\end{array}$ & $\begin{array}{l}\text { A new } X P C \text { poly(AT) insertion/deletion } \\
\text { polymorphism }\end{array}$ & $\begin{array}{l}\text { Case-control } \\
\text { study }\end{array}$ & $\begin{array}{l}419 \text { cases, } 219 \\
\text { controls }\end{array}$ & $\begin{array}{l}\text { Four polymorphisms including } \\
\text { A23G in XPA, Lys939GIn in XPC, } \\
\text { and Lys751Gln and Asp312Asn in } \\
X P D\end{array}$ & Significant relationship with the risk of CC \\
\hline $\begin{array}{l}\text { Hansen et al. } \\
(2007)^{(38)}\end{array}$ & $\begin{array}{l}X P A \text { A23G, XPC Lys939GIn, XPD } \\
\text { Lys751GIn and XPD Asp312Asn } \\
\text { polymorphisms, interactions with smoking, } \\
\text { alcohol and dietary factors, and risk of CRC }\end{array}$ & $\begin{array}{l}\text { Case-control } \\
\text { study }\end{array}$ & $\begin{array}{l}405 \text { CRC cases, } \\
810 \text { controls }\end{array}$ & $\begin{array}{l}\text { XPC Lys939GIn, XPA A23G, XPD } \\
\text { Lys751Gln, and XPD Asp312Asn } \\
\text { polymorphisms }\end{array}$ & $\begin{array}{l}\text { This study showed lower risk of cancer in women } \\
\text { with Lys751Gln polymorphism of } X P D \text { and in } \\
\text { homozygous individuals for XPC Lys939GIn } \\
\text { polymorphism increased CC }\end{array}$ \\
\hline $\begin{array}{l}\text { Joshi et al. } \\
(2009)^{(39)}\end{array}$ & $\begin{array}{l}\text { Red meat and poultry intake, } \\
\text { polymorphisms in the nucleotide excision } \\
\text { repair and mismatch repair pathways and } \\
\text { CRC risk }\end{array}$ & $\begin{array}{l}\text { Case-control } \\
\text { study }\end{array}$ & $\begin{array}{l}577 \text { cases, } 307 \\
\text { controls }\end{array}$ & $X P D$ 312ASP and XPD 751Lys & $\begin{array}{l}\text { People with high consumption of red meat and } \\
X P D 312 A S P \text { and } X P D 751 \text { Lys risk alleles have a } \\
\text { higher chance of CRC. The consumption of poultry } \\
\text { meat in the carriers of the } X P D 751 \text { Lys allele } \\
\text { increased risk of CC }\end{array}$ \\
\hline $\begin{array}{l}\text { Steck et al. } \\
(2014)^{(40)}\end{array}$ & $\begin{array}{l}\text { Nucleotide excision repair gene } \\
\text { polymorphisms, meat intake and colon } \\
\text { cancer risk }\end{array}$ & $\begin{array}{l}\text { Case-control } \\
\text { study }\end{array}$ & $\begin{array}{l}331 \text { African } \\
\text { Americans with } \\
\text { colon cancer, } 544 \\
\text { controls }\end{array}$ & $\begin{array}{l}\text { XPC (A499V and K939Q), XPD } \\
\text { (D312N and K751Q), XPF } \\
\text { (R415Q), XPG (D1104H) } \\
\text { genotypes }\end{array}$ & $\begin{array}{l}\text { This study showed the statistically significant } \\
\text { positive association between colon cancer risk and } \\
\text { XPC } 499 \mathrm{AV}+\mathrm{VV} \text { genotype and an inverse } \\
\text { association with XPC } 939 \mathrm{QQ}\end{array}$ \\
\hline \multicolumn{6}{|c|}{ DNA mismatch repair (MutS) } \\
\hline $\begin{array}{l}\text { Berndt et al. } \\
(2007)^{(41)}\end{array}$ & $\begin{array}{l}\text { Mismatch repair polymorphisms and the } \\
\text { risk of CRC }\end{array}$ & $\begin{array}{l}\text { Case-control } \\
\text { study }\end{array}$ & $\begin{array}{l}237 \text { CRC cases } \\
\text { and a subcohort of } \\
2189 \text { participants }\end{array}$ & $\begin{array}{l}\text { Four SNP in three mismatch repair } \\
\text { genes (MSH3 R940Q, MSH3 } \\
\text { T1036A, MSH6 G39E and MLH1 } \\
\text { I219V) were genotyped }\end{array}$ & $\begin{array}{l}\text { Processed meat intake appeared to modify the } \\
\text { association between } M S H 3 \text { polymorphisms and } \\
\text { CRC }\end{array}$ \\
\hline
\end{tabular}

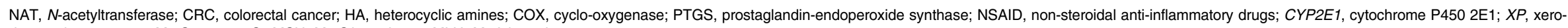
derma pigmentosum; MutS, mutator S; MSH, MutS homolog 3; MLH, MutL homolog 1. 
$\mathrm{CRC}^{(29)}$. Interestingly, Morita et al. ${ }^{(30)}$ showed that there is a significant relationship between red meat consumption and an increased risk of $\mathrm{CC}$ in the individuals carrying the RsaI C2 allele. However, another study reported that no significant relationship was observed between the the CYP2E1 RsaI polymorphism, red meat consumption and $\mathrm{CC}^{(31)}$.

CYP1A2, a member of the cytochrome P450 mixed-function oxidase system, is involved in the metabolism of xenobiotics in the body ${ }^{(32)}$. Some studies have shown that individuals carrying CYP1A2 polymorphisms are at higher risk of developing rectal cancer but not for $\mathrm{CC}^{(33-35)}$. In a case-control study on CYP1A2 polymorphisms, it was found that there was a significant relationship between the consumption of cooked meat at high temperature in $-154 \mathrm{~A}>\mathrm{C}$ polymorphism carriers of CYP1A2 and the risk of CRC. Overall, it is possible that CYP2E1 and CYP1A2 gene polymorphisms may have a role in CRC risk, especially in people with higher meat intake.

\section{Nucleotide excision repair pathway}

The nucleotide excision repair (NER) pathway plays an important role in repairing damaged DNA. The NER pathway is a particularly important excision mechanism that removes DNA damage induced by UV light and environmental carcinogens ${ }^{(36)}$. Xeroderma pigmentosum (XP) complementation group A (XPA), XP complementation group C (XPC) and XP complementation group D (XPD) are important enzymes in the NER pathway. There is a significant relationship between polymorphisms in XPA, XPC and XPD and a lower capacity of DNA repair. Numerous polymorphisms of NER genes have been identified and these changes individually or in combination may adversely affect NER fidelity, which could contribute to the risk of CRC. Four polymorphisms of these genes including A23G in XPA, Lys939Gln in $X P C$, and Lys751Gln and Asp312Asn in XPD have been identified that may have a significant relationship with the risk of $\mathrm{CC}^{(37)}$. For example, in a study conducted by Hansen et al. ${ }^{(38)}$, a lower risk of cancer was reported in women with the Lys751Gln polymorphism of XPD. In homozygous individuals with the XPC Lys939Gln polymorphism, the risk of CC was increased by 3.7 times per $100 \mathrm{~g} / \mathrm{d}$ increased intake of red meat. In the individuals carrying the wild-type allele, meat has no effect on CRC. No significant relationship was observed between other polymorphisms and CC.

Moreover, it was shown that people with a high consumption of red meat and XPD 312Asp and XPD 751 Lys risk alleles have a higher chance of developing CRC than those with XPD $312 \mathrm{Asn}$ and XPD $751 \mathrm{Gln}$ alleles ${ }^{(39)}$. There is also a statistically significant interaction between Lys939Gln of XPC and A23G of $X P A$ with red meat and processed meat intake and the risk of $\mathrm{CC}^{(38,40)}$. Overall, it can be concluding that higher meat intake may have a role in CRC risk, especially in people with polymorphisms in genes involved in the NER pathway.

\section{DNA mismatch repair (mutator $S$ )}

A DNA mismatch repair protein, also known as mutator $\mathrm{S}$ (MutS), participates in the DNA mismatch repair system. In a study conducted on the polymorphisms of this gene, it was found that some gene polymorphisms were associated with an increased risk of CC. Processed meat intake could increase CC risk in people with the MutS polymorphism ${ }^{(41)}$. In another study, a significant relationship was observed between processed meat intake, the - polymorphism of the MutS gene and the risk of $\mathrm{CC}^{(42)}$. In general, it can be concluded that MutS polymorphisms may have a role in CRC risk, especially in people with higher processed meat intake.

\section{Discussion}

The presence of SNP associated with the metabolism and function of proteins could play an important role in the effects of red meat consumption on the risk of CC.

Several individual SNP have been associated with CC risk. It is plausible that a set of SNP derived from genetic pathways that are critical in colon carcinogenesis could contribute to the cancer risk. We investigated the role of polymorphisms involved in five metabolic pathways that are relevant for the activation or detoxification of carcinogens formed during red meat processing. The polymorphisms investigated in the present study were mostly functional polymorphisms that alter the expression of genes participating in metabolic pathways associated with carcinogenesis ${ }^{(43)}$.

Recent studies demonstrated the modifier role of NAT2 G857A, COX-2 rs20417, CYP2E1 RsaI, CYP1A2 154A>C, XPC Lys939Gln, XPA A23G and MutS T1036A on the effect of red meat consumption on CRC risk. However, some studies failed to identify an association between red meat consumption and the effect of these polymorphisms on CRC risk. Possible explanations for the discrepancy might include differences in meat variable definitions, and lack of stratification by tumour subsite in these studies. Moreover, other factors including frequency of turning the meat over during the cooking process, meat thickness, cut of meat, use of marinade or thawing meat in the microwave were not considered and may have contributed to these contradictory results ${ }^{(44)}$.

\section{Conclusion}

In conclusion, some gene polymorphisms may have a significant role in CRC risk, especially in people with higher processed meat intake. Increasing the knowledge on nutritional genomics can lead to the finding of new methods to prevent, treat and control of CC. A summary of descriptions of studies is presented in Table 1.

\section{Acknowledgements}

This study was funded by the Student Research Committee of Shahid Beheshti University of Medical Sciences, Tehran, Iran (code 1396/54017). The authors contributed equally to this work.

None of the authors reported a conflict of interest related to the study. 


\section{References}

1. Slattery ML, Yakumo K, Hoffman M, et al. (2004) Variants of the VDR gene and risk of colon cancer (United States). Cancer Causes Control 12, 359-364.

2. Kolahdoozan SH, Sadjadi A, Radmard A, et al. (2010) Five common cancers in Iran. Arch Iran Med 13, 143-146.

3. Becker N (2003) Epidemiology of colorectal cancer. Radiologe 43, 98-104.

4. Schwartz SI (1999) Principles of Surgery, 7th ed., pp. 1328-1352. New York: McGraw Hill.

5. Borji M (2017) Investigating the effect of home care on death anxiety in patients with gastrointestinal cancer. Govaresh 22, 131-132.

6. Doaei S, Kalantari N, Mohammadi NK, et al. (2017) Macronutrients and the FTO gene expression in hypothalamus; a systematic review of experimental studies. Indian Heart J 69, 277281.

7. Kalantari N, Doaei S, Keshavarz-Mohammadi N, et al. (2016) Review of studies on the fat mass and obesity-associated (FTO) gene interactions with environmental factors affecting on obesity and its impact on lifestyle interventions. ARYA Atheroscler 12, 281.

8. Akbari ME, Doaei S, Gholamalizadeh M, et al. (2018) FTO gene affects obesity and breast cancer through similar mechanisms: a new insight into the molecular therapeutic targets. Nutr Cancer 70, $30-36$.

9. Kalantari N, Mohammadi NK, Rafieifar S, et al. (2017) Indicator for success of obesity reduction programs in adolescents: body composition or body mass index? Evaluating a school-based health promotion project after 12 weeks of intervention. Int J Prev Med $\mathbf{8}$, 73.

10. Le Marchand L, Donlon T, Seifried A, et al. (2002) Red meat intake, CYP2E1 genetic polymorphisms, and colorectal cancer risk. Cancer Epidemiol Biomarkers Prev 11, 1019-1024.

11. Brink M, Weijenberg MP, De Goeij AF, et al. (2005) Meat consumption and K-ras mutations in sporadic colon and rectal cancer in The Netherlands Cohort Study. Br J Cancer 92, 1310.

12. Wang H, Iwasaki M, Haiman CA, et al. (2015) Interaction between red meat intake and NAT2 genotype in increasing the risk of colorectal cancer in Japanese and African Americans. PLOS ONE 10, e0144955.

13. Ananthakrishnan AN, Du M, Berndt SI, et al. (2015) Red meat intake, NAT2, and risk of colorectal cancer: a pooled analysis of 11 studies. Cancer Epidemiol Biomarkers Prev 24, 198-205.

14. Sørensen M, Autrup H, Olsen A, et al. (2008) Prospective study of NAT1 and NAT2 polymorphisms, tobacco smoking and meat consumption and risk of colorectal cancer. Cancer Lett 266, 186193.

15. Lilla C, Verla-Tebit E, Risch A, et al. (2006) Effect of NAT1 and NAT2 genetic polymorphisms on colorectal cancer risk associated with exposure to tobacco smoke and meat consumption. Cancer Epidemiol Biomarkers Prev 15, 99-107.

16. Barrett JH, Smith G, Waxman R, et al. (2003) Investigation of interaction between $N$-acetyltransferase 2 and heterocyclic amines as potential risk factors for colorectal cancer. Carcinogenesis 24, 275-282.

17. Procopciuc LM, Osian G \& Iancu M (2017) N-acetyl transferase 2/ environmental factors and their association as a modulating risk factor for sporadic colon and rectal cancer. J Clin Lab Anal 5, e22098.

18. Da Silva TD, Felipe AV, de Lima JM, et al. (2011) $\mathrm{N}$-acetyltransferase 2 genetic polymorphisms and risk of colorectal cancer. World J Gastroenterol 17, 760-765.

19. Tiemersma EW, Kampman E, Bueno de Mesquita HB, et al. (2002) Meat consumption, cigarette smoking, and genetic susceptibility in the etiology of colorectal cancer: results from a Dutch prospective study. Cancer Causes Control 13, 383-393.

20. Chan AT, Tranah GJ, Giovannucci EL, et al. (2005) Prospective study of $\mathrm{N}$-acetyltransferase- 2 genotypes, meat intake, smoking and risk of colorectal cancer. Int J Cancer 115, 648-652.
21. Shalaby MA, Nounou HA, Ms A, et al. (2014) Associations between single nucleotide polymorphisms of COX-2 and MMP-2 genes and colorectal cancer susceptibility in the Saudi population. Asian Pac J Cancer Prev 15, 4989-4994.

22. Makar KW, Poole EM, Resler AJ, et al. (2013) COX-1 (PTGS1) and COX-2 (PTGS2) polymorphisms, NSAID interactions, and risk of colon and rectal cancers in two independent populations. Cancer Causes Control 24, 2059-2075.

23. Peng Q, Yang S, Lao X, et al. (2014) Meta-analysis of the association between $C O X-2$ polymorphisms and risk of colorectal cancer based on case-control studies. PLOS ONE 9, e94790.

24. Andersen V, Holst R, Kopp TI, et al. (2013) Interactions between diet, lifestyle and IL10,IL1B, and PTGS2/COX-2 gene polymorphisms in relation to risk of colorectal cancer in a prospective Danish case-cohort study. PLOS ONE 8, e78366.

25. Yoshida K, Osawa K, Kasahara M, et al. (2007) Association of CYP1A1, CYP1A2, GSTM1 and NAT2 gene polymorphisms with colorectal cancer and smoking. Asian Pac J Cancer Prev 8, 438-444.

26. Hayashi S, Watanabe J \& Kawajiri K (1991) Genetic polymorphisms in the $5^{\prime}$-flanking region change transcriptional regulation of the human cytochrome P450IIE1 gene. J Biochem 110, 559-565.

27. Shahriary GM, Galehdari H, Jalali A, et al. (2012) CYP2E1* 5b, CYP2E1* 6, CYP2E1* 7B, CYP2E1*2, and CYP2E1* 3 allele frequencies in Iranian populations. Asian Pac J Cancer Prev 13, 65056510

28. Van der Logt EMJ, Bergevoet SM, Roelofs HMJ, et al. (2006) Role of epoxide hydrolase, NAD(P)H:quinone oxidoreductase, cytochrome P450 2E1or alcohol dehydrogenase genotypes in susceptibility to colorectal cancer. Mutat Res 593, 39-49.

29. Gao CM, Takezaki T, Wu JZ, et al. (2007) CYP2E1 Rsa I polymorphism impacts on risk of colorectal cancer association with smoking and alcohol drinking. World J Gastroenterol 13, 5725-5730.

30. Morita M, Le Marchand L, Kono S, et al. (2009) Genetic polymorphisms of CYP2E1 and risk of colorectal cancer: The Fukuoka Colorectal Cancer Study. Cancer Epidemiol Biomarkers Prev 18, 235-241.

31. Silva TD, Felipe AV, Pimenta CA, et al. (2012) CYP2E1 RsaI and 96-bp insertion genetic polymorphisms associated with risk for colorectal cancer. Genet Mol Res 11, 3138-3145.

32. Wang J, Joshi AD, Corral R, et al. (2012) Carcinogen metabolism genes, red meat and poultry intake, and colorectal cancer risk. Int J Cancer 130, 1898-1907.

33. Le Marchand L, Wilkinson GR \& Wilkens LR (1999) Genetic and dietary predictors of CYP2E1 activity: a phenotyping study in Hawaii Japanese using chlorzoxazone. Cancer Epidemiol Biomark Prev 8, 495-500.

34. Le Marchand L, Hankin JH, Wilkens LR, et al. (2001) Combined effect of well-done red meat, smoking and rapid $N$-acetyltransferase 2 and CYP1A2 phenotypes in increasing colorectal cancer risk. Cancer Epidemiol Biomark. Prev 10, 1259-1266.

35. Cotterchio M, Boucher BA, Manno M, et al. (2008) Red meat intake, doneness, polymorphisms in genes that encode carcinogenmetabolizing enzymes, and colorectal cancer risk. Cancer Epidemiol Biomarkers Prev 17, 3098-3107.

36. Qiao Y, Spitz MR, Shen H, et al. (2002) Modulation of repair of ultraviolet damage in the host-cell reactivation assay by polymorphic XPC and XPD/ERCC2 genotypes. Carcinogenesis 23, 295-299.

37. Khan SG, Metter EJ, Tarone RE, et al. (2000) A new xeroderma pigmentosum group C poly(AT) insertion/deletion polymorphism. Carcinogenesis 21, 1821-1825.

38. Hansen RD, Sørensen M, Tjønneland A, et al. (2007) XPA A23G, XPC Lys939Gln, XPD Lys751Gln and XPD Asp312Asn polymorphisms, interactions with smoking, alcohol and dietary factors, and risk of colorectal cancer. Mutat Res Fundam Mol Mech Mutagen 619, 68-80.

39. Joshi AD, Corral R, Siegmund KD, et al. (2009) Red meat and poultry intake, polymorphisms in the nucleotide excision repair and mismatch repair pathways and colorectal cancer risk. Carcinogenesis 30, 472-479. 
40. Steck SE, Butler LM, Keku T, et al. (2014) Nucleotide excision repair gene polymorphisms, meat intake and colon cancer risk. Mutat Res Fundam Mol Mech Mutagen 762, 24-31.

41. Berndt SI, Platz EA, Fallin MD, et al. (2007) Mismatch repair polymorphisms and the risk of colorectal cancer. Int J Cancer 120, 1548-1554.

42. Laporte GA, Leguisamo NM, Kalil AN, et al. (2018) Clinical importance of DNA repair in sporadic colorectal cancer. Crit Rev Oncol Hematol 126, 168-185.
43. Goodman JE, Mechanic LE, Luke BT, et al. (2006) Exploring SNP-SNP interactions and colon cancer risk using polymorphism interaction analysis. Int J Cancer 118, 1790-1797.

44. Ho V, Peacock S, Massey TE, et al. (2014) Meat-derived carcinogens, genetic susceptibility and colorectal adenoma risk. Genes Nutr $9,430$.

45. Zhu W, Wei BB, Shan X, et al. (2010) $-765 \mathrm{G}>\mathrm{C}$ and $8473 \mathrm{~T}>\mathrm{C}$ polymorphisms of $C O X-2$ and cancer risk: a meta-analysis based on 33 case-control studies. Mol Biol Rep 37, 277-288. 